\title{
On the Physical Sense of Isotope Composition of Carbonate and Organic Carbon in Sedimentary Rocks and Its Possible Use in Stratigraphy
} Ivlev AA

Russian State Agrarian University, Timiryazevskaya ul., 49, Moskva, Russia, 127550

\begin{abstract}
The physical sense of carbon isotope composition of coeval organic matter and carbonates in sedimentary rocks, which widely used in geological studies and for stratigraphic correlations, was considered. The isotopic differences of the above parameters were grouped into two types. The first type, termed facial isotopic differences, reflects a variety of photosynthesis conditions in separate locations at the moment. In this scale the parameters are independent on time. The second type, dependant on time, consists of the temporal isotopic differences associated with orogenic cycles and those associated with climatic oscillations appearing after the system reached ecological compensation point. Isotopic differences associated with orogenic cycles take into account only cyclic variations (from cycle to cycle) and irreversible motion of carbon cycle system to the ecological compensation point and change in geological time. Isotopic differences associated with climatic oscillations take into account only cyclic variation around ecological compensation point. The latter have most efficient application in geological and stratigraphic correlations
\end{abstract}

\section{Publication History:}

Received: February 20, 2017

Accepted: August 10, 2017

Published: August 12, 2017

\section{Keywords:}

Carbonates, Organic carbon, Photosynthesis, Carbon isotope differences, Orogenic cycles, Climatic oscillations, Ecological Compensation point.

\section{Introduction}

\section{General approach to physico-chemical analysis of isotope fractionation in geologic systems}

Isotope composition of carbonate and organic carbon are widely used in different geologic and stratigraphic correlations. It is commonly done on the empirical basis. Isotope composition is seen as if it is a constant property of the studied object and the observed discrepancies of isotopic characteristics are explained by some assumed peculiarities of a geological system.

Such approach is not correct, since isotope composition is not a constant, but a function of one or more physico-chemical processes in the system which, according to the laws, should be followed by isotope fractionation. The actualism principle is the basis for such analysis. It states the independence of physico-chemical laws on time providing the environmental conditions in the past and allows considering the processes in the geological past, including isotope fractionation, from the standpoints of present knowledge.

In the present work the variations of isotope composition of coeval carbonate and organic carbon in global carbon cycle caused by environmental changes in the past are considered. Since the theoretical and experimental validity of the carbon model itself was considered before $[1,2]$, here we'll focus our attention on isotopic composition of carbonate and organic carbon in sedimentary rocks and their possible use for geological and stratigraphic correlations.

\section{Discussion}

The relationship between carbonate and organic carbon stemming from the key role of photosynthesis in global carbon cycle

According to the model, photosynthesis is the only source of organic mater in sedimentary rocks. The carbon substrate for the photosynthesis is inorganic carbon $\left(\mathrm{CO}_{2}-\mathrm{HCO}_{3}--\mathrm{CO}_{3}=\right)$ in the "atmosphere - hydrosphere" system, which in turn is formed in oxidation of previously deposited organic carbon. The oxidation proceeds in thermochemical sulfate reduction in subduction zones during orogenic period of the cycle [1].
It was shown [3] that carbon isotope composition of carbonates may be used to describe isotopic variations of coeval $\mathrm{CO} 2$, since it is a part of isotope exchange chemical system which is in equilibrium. Just as well organic matter coeval "living" matter may be used to examine its isotopic variations emerged in photosynthesis

Here some explanations should be done. The thing is that V.I. Vernadsky, who introduced the term "living matter" in 1926 [4], meant the total biomass of all living organisms, including photosynthesizing ones. Keeping in mind that photosynthesizing biomass is an initial substrate for any food chain, we can conclude that "living matter" finally is a product of photosynthesis. From this standpoint, its carbon isotope composition can be regarded as a result of isotope fractionation in photosynthesis. The assertion is particularly true since it is known that carbon isotope fractionation in heterotrophic assimilation is insignificant and isotope composition of the whole "living matter" is mainly determined by photosynthesizing biomass.

Carbon isotope composition of "living matter" slightly differs from that of organic matter. The cause of the difference is isotope heterogeneity of the biomass as a result of intracellular isotope fractionation; and subsequent partial oxidation of different fractions of the "living" matter after burial.

Indeed, if one takes into consideration that the maximal isotopic differences observed between lipid - protein and carbohydrate fractions are around 5\%o (in most cases much less), and have in mind that the whole range of isotopic differences related to the photosynthesis conditions in different ecosystems are up to $20 \%$ or

"Corresponding Author: Dr. Ivlev AA, Russian State Agrarian University, Timiryazevskaya ul., 49, Moskva, 127550, Russia; E-mail: aa.ivlev@list.ru

Citation: Ivlev AA (2017) On the Physical Sense of Isotope Composition of Carbonate and Organic Carbon in Sedimentary Rocks and Its Possible Use in Stratigraph. Int J Earth Environ Sci 2: 136. doi: https://doi.org/10.15344/2456$351 \mathrm{X} / 2017 / 136$

Copyright: (C) 2017 Ivlev. This is an open-access article distributed under the terms of the Creative Commons Attribution License, which permits unrestricted use, distribution, and reproduction in any medium, provided the original author and source are credited. 
Citation: Ivlev AA (2017) On the Physical Sense of Isotope Composition of Carbonate and Organic Carbon in Sedimentary Rocks and Its Possible Use in Stratigraph. Int J Earth Environ Sci 2: 136. doi: https://doi.org/10.15344/2456-351X/2017/136

Page 2 of 6

more, it can be argued that the isotope composition of sedimentary organic matter should be determined mainly by the photosynthesis conditions in the ecosystems. Thus carbon isotope composition of organic matter repeats mostly variations of "living matter".

\section{Two crucial assumptions of the global carbon cycle model}

It is known that lithospheric plates are in permanent movement. One of the crucial assertions of the global carbon cycle model is that the irregular and cyclic development of photosynthesis is a consequence of irregular movement of lithospheric plates. It was assumed that intense fluctuations of the Earth crust [5] correspond to the quick rates of lithospheric plates. The period of this movement, which is a relatively short, is termed orogenic one. The time of quiet development of the Earth crust that corresponds to a relatively long period is termed geosynclynal. It is characterized by dominant role of photosynthesis and weathering. Both periods compose orogenic cycle. The lithospheric plates' movement is followed by collisions. The collisions in turn are accompanied with energy evolution that stimulates thermochemical sulfate reduction where organic matter is oxidized. The $\mathrm{CO}_{2}$ formed in oxidation intensifies photosynthesis.

The important conclusion may be done from this assertion. Photosynthesis development also consists of orogenic and geosynclynal periods. In orogenic period "atmosphere - hydrosphere" system is filled with $\mathrm{CO}_{2}$. The rate of the photosynthesis is high. In geosynclynal period photosynthesis rate the $\mathrm{CO}_{2}$ (inorganic carbon pool) begins to deplete.

Another crucial point of the model, stemming from actualism principle, leads to the assertion that photosynthesis in the past has the same features as photosynthesis of modern photosynthesizing organisms, i.e. consists of two reciprocal processes - $\mathrm{CO}_{2}$ assimilation and photorespiration. The strengthening of one of them is accompanied by the weakening of the other. The effect of each of the processes on the total biomass growth is opposite and depends on the concentration ratio of the $\mathrm{CO}_{2}$ and $\mathrm{O}_{2}$ in the environment. The increase of $\mathrm{CO}_{2}$ concentration enhances the $\mathrm{CO}_{2}$ assimilation and supplies the total biomass growth whereas the increase in oxygen concentration stimulates photorespiration and reduces the total biomass. Moreover it is accompanied by carbon isotope fractionation. $\mathrm{CO}_{2}$ assimilation is followed by the enrichment of the total biomass in a "light" isotope ${ }^{12} \mathrm{C}$ relative to the assimilated carbon, while photorespiration leads to the enrichment of the total biomass in a "heavy" isotope ${ }^{13} \mathrm{C}$. The carbon isotope composition of the total biomass depends on the relative contribution of the two above processes to the biosynthesis. The increase of $\mathrm{CO}_{2}$ concentration in the environment leads to the ${ }^{12} \mathrm{C}$ enrichment of the biomass, whereas the $\mathrm{O}_{2}$ growth in the atmosphere provides ${ }^{13} \mathrm{C}$ enrichment of the total biomass. Organic matter undergoes the corresponding isotopic shifts.

There are two reasons providing ${ }^{13} \mathrm{C}$ enrichment of organic matter in geosynclynal period. The first is the growth of oxygen in the atmosphere due to photosynthesis and corresponding intensification of photorespiration. It provides the successive ${ }^{13} \mathrm{C}$ enrichment of organic matter by the end of the period. The second reason is the Raleigh effect accompanying $\mathrm{CO}_{2}$ pool depletion which is also followed by ${ }^{13} \mathrm{C}$ accumulation in the residual $\mathrm{CO}_{2}$ and in the newly formed organic matter. Thus the sequential ${ }^{13} \mathrm{C}$ enrichment of organic matter and carbonates, deposited in the course of geosynclynal period, should take place.
The said above is particularly interesting, since the coeval carbonates and organic matter are the most frequent objects in geology studies, as well as carbon isotope determinations are trivial. It is supported by the use of the correlation of $\varepsilon\left(\delta^{13} \mathrm{C}_{\text {carb }}-\delta^{13} \mathrm{C}_{\text {org.matter }}\right)$, with different characteristics proportional to the oxygen content [6-8].

\section{Facial carbon isotope differences}

Facial carbon isotope differences in non-oxidative Precambrian atmosphere

Protobionts, living in Precambrian, needed oxygen to supply their energy metabolism. However because of anoxic atmosphere in Precambrian they were enforced to take it from oxygen-containing compounds. Carbon dioxide was prevalent in primitive "atmosphere - hydrosphere" system. It contributed to the occurrences of bacteria methanogens that utilized $\mathrm{CO}_{2}$ as a source of oxygen and produced methane [9]. If so, it may be assumed that anomalous "heavy" residual carbonates, found in paleoproterozoic rocks $(2,6-1.9 \mathrm{Ma})$, are formed from the residual $\mathrm{CO}_{2}$ enriched in $13 \mathrm{C}$ due to Raleigh effect and following isotope exchange reactions in natural "carbon dioxide - bicarbonate - carbonate" system. This is confirmed by the isotope fractionation in modern anaerobic environments [10 12]. The Raleigh effect, which commonly accompanies the isotope fractionation in natural conditions, strengthens isotopic discrepancies by multiplying one-off isotope effects of the reactions.

\section{Facial carbon isotope differences in non-oxidative Precambrian atmosphere}

Later, when molecular oxygen has appeared in the atmosphere, methane was oxidized and disappeared. Gradually the energy supply through the respiration replaced the reaction of conversion of $\mathrm{CO}_{2}$ into $\mathrm{CH}_{4}$. Evolution of photosynthesis resulted in photorespiration emergence. Simultaneously with photorespiration carbon isotope effect of opposite sign, in respect to $\mathrm{CO}_{2}$ assimilation, has appeared.

In response to these changes in the environment, facial isotopic differences, corresponding to different photosynthesis conditions, caused by different $\mathrm{CO}_{2} / \mathrm{O}_{2}$ ratios, which in turn determine different $\mathrm{CO}_{2}$ assimilation/photorespiration ratios in metabolism, have appeared. Besides the above ratio there are some other environmental factors exerting an impact on carbon isotope composition of biomass and organic matter as well, such as: light intensity, salinity, water circulation, water availability, etc. They determine the range of carbon isotope variations about $20 \%$ o for the limiting conditions [13]. However, the limiting cases occur in the nature very seldom and isotope variations commonly are much smaller.

The initial carbon isotope heterogeneity of a "living matter" is transferred to organic matter via different rate of oxidation of biomass fractions occurring in sediments and diagenesis. However the effect of this factor is insignificant as compared with isotopic shifts conditioned by photosynthesis conditions. Indeed, if to compare maximal isotope differences, found between carbohydrate - protein and lipid fractions, which are about 5-6\%, with the isotopic variations of biomass for different facial conditions which are about $20 \%$, the expected difference in both cases becomes evident. Keep in mind, among different factors affecting on the facial isotope variations the $\mathrm{CO}_{2} / \mathrm{O}_{2}$ concentration ratio in the environment plays a dominant role. Some other factors influencing on isotope variations are also depend on the above ratio. For example, the increase of water salinity leads to the visible ${ }^{13} \mathrm{C}$ isotope enrichment of biomass. It is explained by a decrease in oxygen solubility in water and hence by low photorespiration of 
Citation: Ivlev AA (2017) On the Physical Sense of Isotope Composition of Carbonate and Organic Carbon in Sedimentary Rocks and Its Possible Use in Stratigraph. Int J Earth Environ Sci 2: 136. doi: https://doi.org/10.15344/2456-351X/2017/136

Page 3 of 6

water organisms. In particular, the $13 \mathrm{C}$ enrichment of terrestrial organic matter as compared with organic matter of marine type as well as the ${ }^{13} \mathrm{C}$ enrichment of organic matter in the course of geosynclynal period, where $\mathrm{O}_{2}$ concentration constantly grows up, is explained by the same manner.

The stratigraphic correlations based on facial isotopic shifts are limited to the frontiers of facial locations.

Temporal carbon isotope shifts in orogenic cycles and in the following after them climatic oscillations

As said, the most "light" organic matter is formed in orogenic period of the cycle when "atmosphere - hydrosphere" system is filled with $\mathrm{CO}_{2}$, derived in oxidation of sedimentary organic matter in subduction zone. Two reasons determine ${ }^{12} \mathrm{C}$ enrichment of newly formed organic matter at the beginning of the cycle. It is isotopically "light" source for $\mathrm{CO}_{2}$ production (sedimentary organic matter) and the low photorespiration (high $\mathrm{CO}_{2}$ assimilation) in photosynthesis.

In the course of geosynclynal period $\mathrm{O}_{2}$ concentration and correspondingly, photorespiration grow up. In parallel with it, $\mathrm{CO}_{2}$ concentration falls causing the appearance of Raliegh effect. The latter leads to additional ${ }^{13} \mathrm{C}$ enrichment of organic matter and carbonates. The "heaviest" carbon isotope composition is achieved by the end of the cycle.

Due to long duration of Proterozoic cycles the extent of $\mathrm{CO}_{2}$ pool depletion was greater than in Phanerozoic ones. It might be possible explanation for anomalous ${ }^{13} \mathrm{C}$ isotope enrichment of carbonates in Precambrian. This explanation is not suitable for organic matter, since Raleigh effect will be compensated by low concentration of $\mathrm{O}_{2}$ in the atmosphere (low photorespiration).

Hereinafter there is an example of orogenic cycle manifestation in Proterozoic [14] (Figure 1), which was disclosed by means of carbon isotope ratio of carbonates. As one can see from Figure 1, there are two negative peaks that can be related to two orogenic periods of different neighboring orogenic cycles. Negative peaks indicate that $\mathrm{CO}^{2}$, filling the atmosphere - hydrosphere" system was produced from the source enriched in ${ }^{12} \mathrm{C}$. Such a source is sedimentary organic matter dropped previously into the sediments and later subjected to oxidation in thermochemical sulfate reduction.

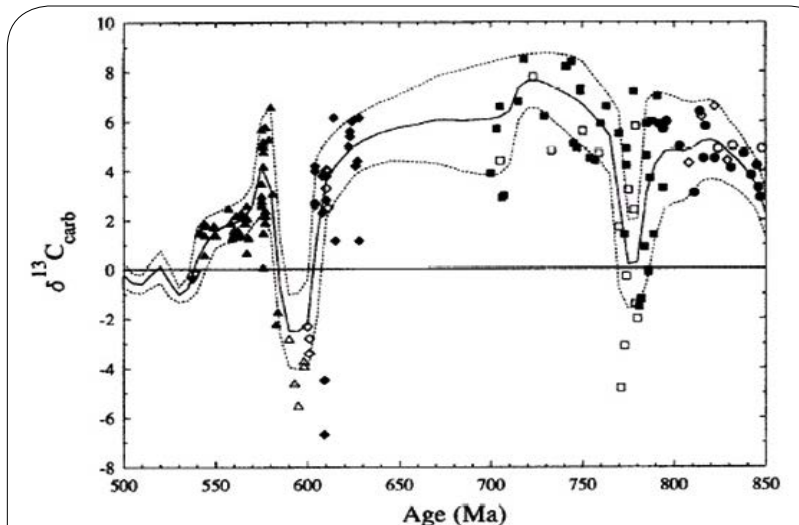

Figure 1: Secular variations in $\delta^{13} \mathrm{C}$ of Late Proterozoic marine carbonates from different stratigraphic groups. Ages of stratigraphic groups were estimated from the best geochronologic information presently available. Figure is taken from Derry et al. (1992). Negative excursion in the $\delta^{13} \mathrm{C}$ curve, according to the model (Ivlev, 2016), correspond to the onset of "greenhouse" period.
The facial isotope shifts, which are always present, fail to hide greater isotopic discrepancies arising in orogenic period. Moreover, temporary isotopic shifts can be easily distinguished due to parallel shifts of some other isotopic and non-isotopic parameters, accompanying transition from geosynclynal period of one cycle to orogenic period of another. They are sulfur isotopic shifts of marine sulfates, nitrogen isotopic shifts of nitrates, oxygen isotopic shifts of carbonates, the change in species composition of flora and fauna directed to thermophylic organisms, sea level growth, etc. All these shifts occur practically at the same time. The sign of shifts and its values have a physical sense. As a rule, the transition from aerobic conditions of geosynclynal period to low oxygen or anoxic conditions of orogenic period is followed by dramatic events in biosphere. Breathing organisms belonging to the higher links of the food chains die, whereas primitive organisms more adapted to anaerobic environments survive [15]. This time corresponds to the formations of deposits rich in organic matter. The numerous evidences of magmatic and volcanic activity are typical to this time.

Bazhenova and Sokolov [16], found the irregular stratigraphic distribution of domanicoids (deposits rich in organic matter). It was disclosed practically in all systems of Phanerozoic and Precambrian, including Ediacaran - Cambrian, Devonian - Carboniferous, late Jurassic - early Cretaceous and evidences for existence of orogenic cycles and its global manifestation.

Orogenic cycles are global and cover the entire planet. The easiest way to detect them is to determine the transition from geosynclynal to orogenic period when the isotopic shifts and changes of other coupled characteristics are maximal. For example, the traits characterizing the orogenic cycle in late Cambrian $\left(\delta^{13} \mathrm{C}_{\text {Corg. matter }}\right.$, sea level growth, deposits rich in organic matter) were found in Great Britain, in Sweden, in North America, and in Siberia [17]. However to find the shifts indicating orogenic cycle is a rather difficult task because of great duration of cycles and the need to obtain a number of measurements to prove them confidently especially in case of stratigraphic correlation.

Carbon isotopic differences of organic matter and carbonates when approaching to the ecological compensation point and after it had been reached

When achieving the ecological compensation point the long-term orogenic cycles were replaced by short-term climatic oscillations. Since orogenic cycles and climatic oscillations have the same reason of origin, namely, lithospheric plates' collisions, one can expect they should be characterized by almost the same set of traits.

Indeed, both have warming and cooling periods. Each period is characterized by a set of traits. Warming period is accompanied by massive $\mathrm{CO}_{2}$ entry into "atmosphere - hydrosphere" system, low oxygen (anaerobic) environment, by numerous traces of magmatic and volcanic activity, by changes in carbon isotope composition of organic matter and carbonates etc. In cooling period changes are opposite.

Short duration of climatic oscillations is the result of extreme sensitivity of the global carbon cycle system to the collisions of separate lithospheric plates. Due to short time of climatic oscillations some differences related to the sequence of the processes, invisible in orogenic cycles, begin to appear. 
Citation: Ivlev AA (2017) On the Physical Sense of Isotope Composition of Carbonate and Organic Carbon in Sedimentary Rocks and Its Possible Use in Stratigraph. Int J Earth Environ Sci 2: 136. doi: https://doi.org/10.15344/2456-351X/2017/136

Page 4 of 6

For comparison, duration of early orogenic cycles, close to photosynthesis origin, was about some hundreds millions years whereas that of climatic oscillations varied from some tens to some hundreds thousands years. As a result, peak on the curves showing time dependence of carbon isotope composition of organic matter on time appears before than the corresponding peak of sulfur isotope composition of marine sulfate. This sequence corresponds to the fact that photosynthesis, where carbon isotope effect appears, takes place before sulfate reduction, where sulfur isotope effect emerges.

The examples of temporal isotopic differences related to climatic oscillations are given in many works [18-21]. Carbon isotope differences of carbonates and organic matter are usually followed by parallel changes of other isotopic and non-isotopic parameters.

The climatic oscillation in the early Jurassic was found one of the first $[18,22]$. It relates to Toarcian oceanic anoxic events. The transition from cooling to warming period was examined in Northern Italy and British Isles. According to the model, a picture of the expected changes corresponding to the transition is the following. The increase of $\mathrm{CO}_{2}$ should lead to formation of biomass and hence to organic matter enriched in ${ }^{12} \mathrm{C}$. It also explains the ${ }^{12} \mathrm{C}$ enrichment of carbonates. Growth of $\mathrm{CO}_{2}$ concentration leads to increase of surface temperature on the Earth and explains the occurrence of thermophylic organisms. Oxygen concentration drops showing antiphase behavior relative to $\mathrm{CO}_{2}$ and causing anoxic situation. The transition from aerobic to anoxic situation leads to mass extinction of organisms and finally to the formation of sediments rich in organic matter. Anoxic situation stimulates distribution of nitrate and sulfate reducing bacteria developing nitrate and sulfate reduction. High concentration of $\mathrm{CO}_{2}$ provides carbonates dissolution owing to the reaction

$$
\mathrm{CO}_{3}={ }_{\text {sediment }}+\mathrm{CO}_{2 \text { soluble gas }}+\mathrm{H}_{2} \mathrm{O}=\mathrm{HCO}_{3}-_{\text {solution }}
$$

All the above traits were noticed by Jenkyns et al. [18]. Data, shown on Figure 2, also support the above picture. One can see negative shifts on curve $\delta^{13} \mathrm{C}_{\text {org. matte }} \mathrm{r}$ which reflects ${ }^{12} \mathrm{C}$ enrichment of organic matter. As said, anoxic conditions, stimulates occurrences of nitrate reducing bacteria, what explains nitrogen isotopic shifts on nitrate isotopic curve. As expected, nitrogen of nitrates is enriched with ${ }^{15} \mathrm{~N}$. The formation of sediments rich in organic matter is illustrated by a peak on the curve describing dependence of organic matter content on time. Very close results were obtained by Sabatino et al. [22] who investigated Toarcian ocean anoxic events in Valdorbia region (Italy). All the observed results found to be not accidental, but regular and interconnected.

Riding et al. [19] have studied Sinemurian substage of early Jurassic (North-Western part of Europe, England). The studied parameters proved the transition from cooling to warming period. The beginning of warming period corresponds to early Sinemurian, the end of warming period to late part of it (Figure 3). The first two curves reflect species changes in flora and fauna in warming period. The occurrence of thermophylic organisms Liasidium variable and Classopollis classoides also confirms the transition to warming period. Negative shifts of $\delta^{13} \mathrm{C}$ on the curves corresponding to polynomorths give additional arguments. Moreover the data show similar shifts that occur for marine (Liasidium variable) as well as for terrestrial environment (Classopollis classoides). Two last curves show carbon and oxygen isotopic excursions for carbonates. Negative carbon isotopic shift for carbonates is explained like negative shift of $\delta^{13} \mathrm{C}_{\text {org }}$ matter in the corresponding curve. It is a result of massive entry of $\mathrm{CO}_{2}$ in warming period enriched in ${ }^{12} \mathrm{C}$. The observed shift of oxygen isotope composition also has the proper explanation. The thing is that oxygen isotope composition of carbonates relates to oxygen isotope exchange $\left({ }^{18} \mathrm{O}\right.$ and $\left.{ }^{16} \mathrm{O}\right)$ between water and soluble carbonates. Isotope effect in this exchange depends on temperature. With temperature "heavy" isotope $18 \mathrm{O}$ accumulates in carbonates, whereas "light" isotope ${ }^{16} \mathrm{O}$ accumulates in water. Due to great prevalence of water it is carbonates that display isotopic shifts. This principle underlies the method of determination of paleotemperatures in ocean in the geological past.

Climatic oscillations were also recorded in different regions of Europe in the early Jurassic, Pliensbachian - Toarcian [23], and Sinemurian - Plienbachian substages [24]. They were revealed in Cretaceous (Aptian substage) [21, 25]. In northern America they

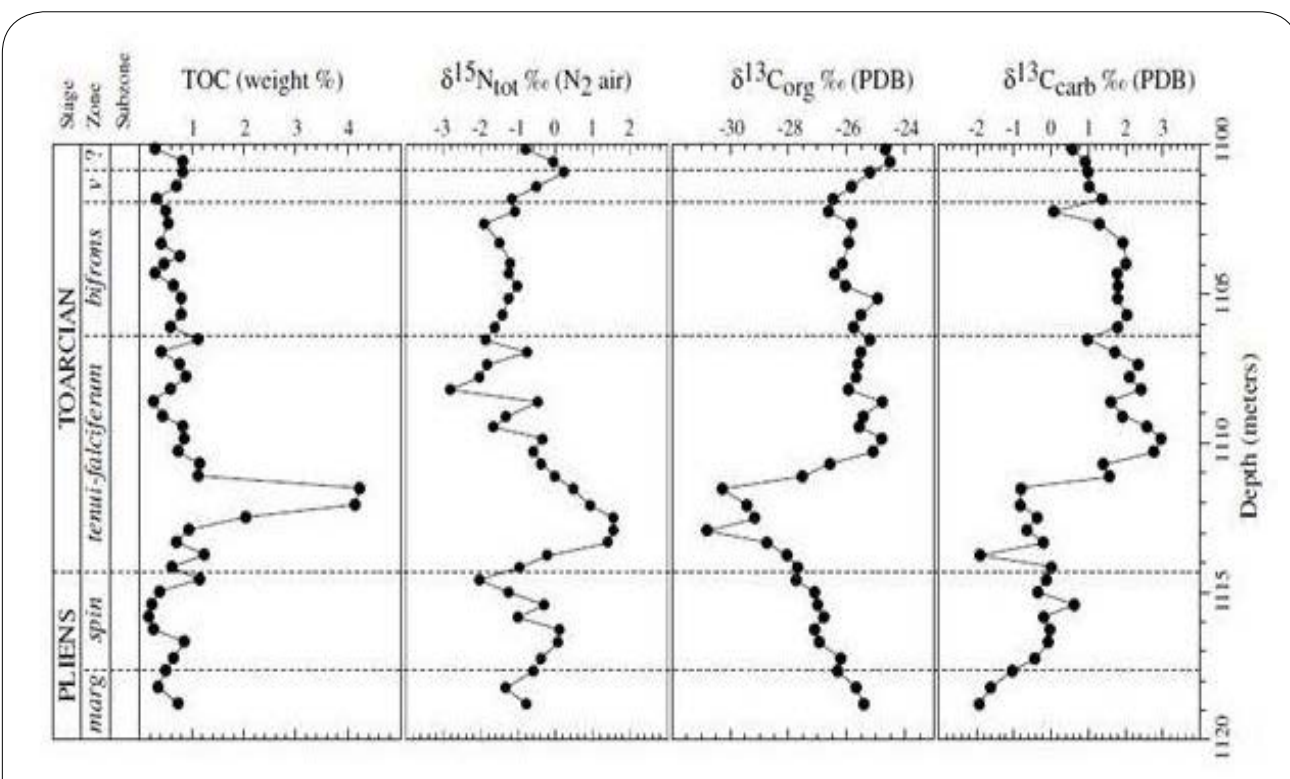

Figure 2: Chemostratigraphic data of Early Urassic (total organic carbon (TOC), $\delta^{15} \mathrm{~N}_{\text {tot }}, \delta^{13} \mathrm{C}_{\text {org }}$, and $\delta^{13} \mathrm{C}_{\text {carb }}$ ) for Winterborne Kingston Borehole, England [18]. 
Citation: Ivlev AA (2017) On the Physical Sense of Isotope Composition of Carbonate and Organic Carbon in Sedimentary Rocks and Its Possible Use in Stratigraph. Int J Earth Environ Sci 2: 136. doi: https://doi.org/10.15344/2456-351X/2017/136

Page 5 of 6

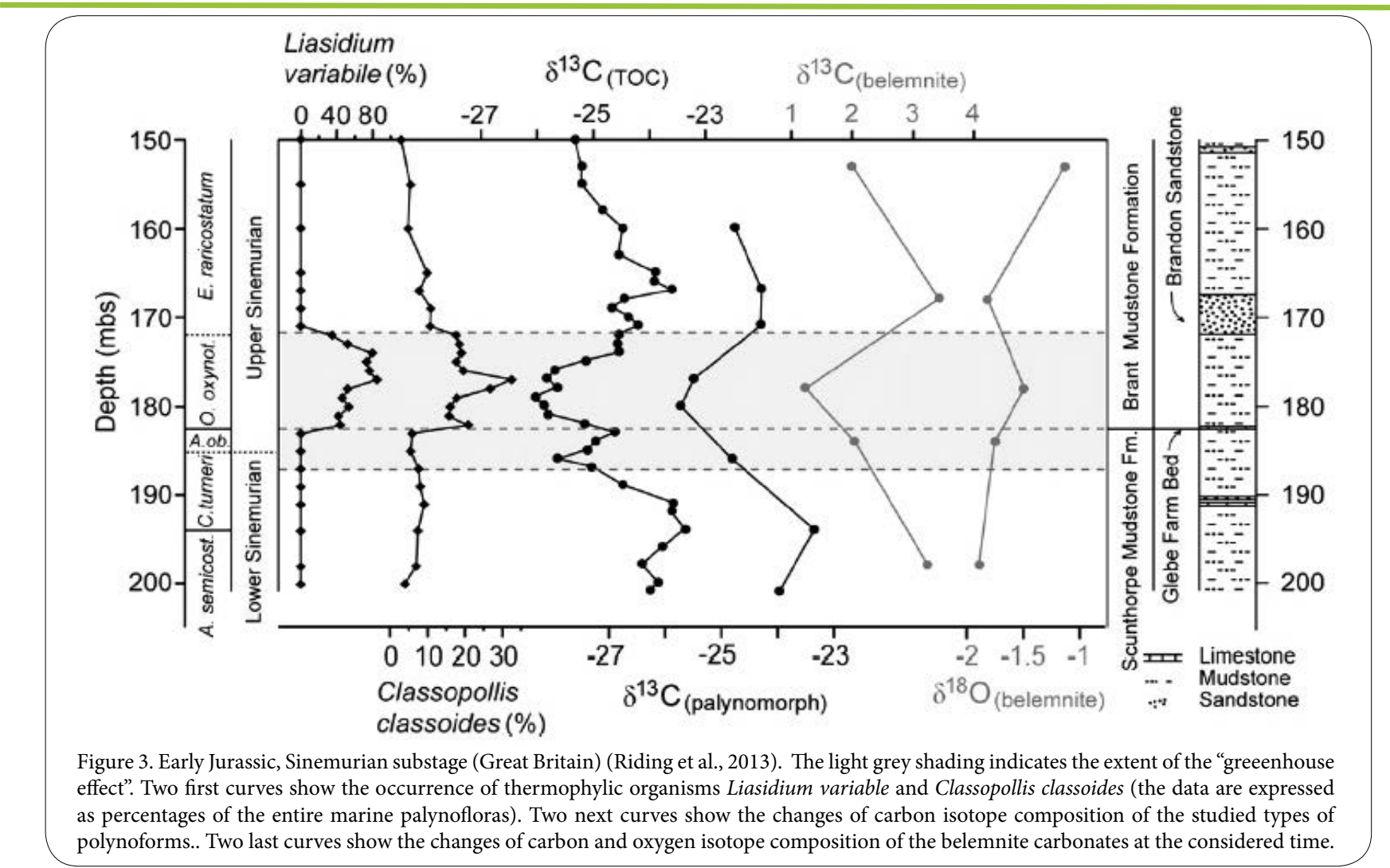

took place at the frontier Oligocene and Miocene [26]. As a rule, climatic oscillation studies were established by examination of cooling/ warming transitions. Like orogenic cycles, climatic oscillations were studied using combination of carbon isotopic differences with other isotopic and non-isotopic parameters. Unlike orogenic cycles, climatic oscillations have regional character, i.e. they arise in the region where they were found. Correspondingly stratigraphic correlations can be used within the region limits.

\section{Conclusion}

The carbon isotope differences of carbonates and sedimentary organic matter are widely used for different geological studies, including stratigraphic correlations. The suggested consideration of physical sense of these isotopic parameters in the frame of global carbon cycle model makes their application for stratigraphic correlations more effective. In the frame of this model all the above parameters are coupled and interconnected. They maybe used together or separately.

The interconditionality of the above isotopic parameters stems from the point of actualism principle stating that carbonates are the analog of $\mathrm{CO}_{2}$, while sedimentary organic matter is analog of "living" matter. Therefore they may be considered as a result of photosynthesis in geological past. Moreover carbon isotopic difference between carbonates and sedimentary organic matter with high accuracy reflects ${ }^{13} \mathrm{C}$ isotope discrimination in photosynthesis.

The analysis of the isotopic changes of the above parameters allows grouping them into two types: facial and temporal isotopic differences. Facial isotopic differences reflect different photosynthesis conditions in various locations on the Earth. The conditions include different concentrations of $\mathrm{CO}_{2}$ and $\mathrm{O}_{2}$ in the environment, illumination, water availability, water salinity and other factors influencing on the above characteristics directly or indirectly.

Facial isotopic differences are manifested in the boundaries of the locations where conditions of photosynthesis are considered to be unchanged. The correlations of the facial isotopic differences with other parameters are valid in the same limits.

Temporal isotopic characteristics include those associated with orogenic cycles and those associated with climatic oscillations. They are time dependant. Carbon isotope differences associated with orogenic cycles takes into account the cyclicity in photosynthesis development as well as irreversible movement of global carbon cycle system in direction to ecological compensation point caused by the accumulation of oxygen in the atmosphere in the course of photosynthesis evolution. The cyclicity of photosynthesis means the similar pattern of the above carbon isotope characteristics within the orogenic cycles.

Irreversible evolution of photosynthesis to the ecological compensation point is manifested as gradual enrichment of sedimentary organic matter in ${ }^{13} \mathrm{C}$ and as a decrease of carbon isotopic discrepancies between carbonates and sedimentary organic matter (decrease of ${ }^{13} \mathrm{C}$ isotope discrimination) in the course of photosynthesis development.

Carbon isotope differences associated with climatic oscillations take into account only cyclic pattern of variations within the oscillations around ecological compensation point. In both mentioned casesthe cyclicity has the similar pattern and is followed by the same set of traits. It is a result of the same nature of the cycles caused by lithospheric plates' collisions. 
Citation: Ivlev AA (2017) On the Physical Sense of Isotope Composition of Carbonate and Organic Carbon in Sedimentary Rocks and Its Possible Use in Stratigraph. Int J Earth Environ Sci 2: 136. doi: https://doi.org/10.15344/2456-351X/2017/136

Page 6 of 6

The most important feature of temporal isotopic differences, that distinguish them from the facial isotopic differences, consists of parallel change of a variety of isotopic and non-isotopic characteristics. The peculiarity of carbon isotope differences associated with climatic oscillations in contrast with those associated with the orogenic cycles consist in ability of the first to distinguish the processes close in time because of their short duration. As a rule, both (cycles and oscillations) are determined using the transition from icing to warming period, since many of the parameters that characterize the periods in these cases vary sharply and simultaneously.

When constructing stratigraphic and other correlations related to orogenic cycles one should keep in mind that traits of cycles might be discovered all over the Earth, since orogenic cycles comprise the entire Earth. On contrary, the traits related to climatic oscillations, might be discovered only in the regions where at the moment lithospheric plates collide. It is established that stratigraphic correlations related to climatic oscillations are used most effectively because of the better geological knowledge of times when ecological compensation point is achieved. Another reason is a greater duration of orogenic cycles. It is required much more samples to characterize transition from orogenic to geosynclynal period which are often not available.

Facial isotopic differences are manifested in the boundaries of the locations where conditions of photosynthesis are considered to be unchanged. The correlations of the facial isotopic differences with other parameters are valid in the same limits.

\section{Competing Interests}

The author declares no financial competing interest.

\section{Acknowledgement}

The author expresses sincere appreciation to Dr. L.K. Pak for his valuable critical comments and for useful discussion on the work.

\section{References}

1. Ivlev AA (2015) Global redox cycle of biospheric carbon: interaction of photosynthesis and earth crust process. BioSystems 137: 1- 11.

2. Ivlev AA (2016) Global carbon cycle and organic matter accumulation in the Earth crust. Geoinfor Goestat: An Overview 4: 1

3. Ivlev AA (2013) Chemical evolution vs Biological evolution: Coupling effect and Consequences, Transworld Research Network, Kerala, India.

4. Vernadsky VI (1926) The Biosphere. Complete Annotated Edition Copernicus Books, New York, 1986.

5. Rutten MG (1971) The Origin of Life by Natural Causes. Elsevier, Amsterdam

6. Popp BN, Takigiku R, Hayes JM, Louda JW, Baker EW (1989) The postPaleozoic chronology and mechanism of $13 \mathrm{C}$ depletion in primary marine organic matter. Am J Sci 289: 436-454.

7. Hayes JM, Popp BN, Takigiku R, Johnson MW (1989) An isotopic study of biogeochemical relationships between carbonates and organic carbon in the Greenhorn Formation. Geochim et Cosm. Acta 53: 2961- 2972.

8. Rothman DH (2001) Global biodiversity and the ancient carbon cycle. Proc Natl Acad Sci USA 98: 4305-4310.

9. Vasconcelos C, Bovler C, Bahnluk A, Anderson MB, McKenzie JA (2016) Unusual very positive enrichment of $13 \mathrm{C}$ in carbonate sediments deposited in modern hypersaline environment, Brazil: Indicator of salinity controlled. 35th Int. Geol. Congress. Cape Town. South Africa. 2016. Paper 2853.
10. Oana S, Deevey ES (1960) Carbon 13C in lake waters, and its possible bearing on paleolimnology. Am J Sci 258A: 253-272.

11. Wada E, Kadonaga T, Natsuo S (1975) $15 \mathrm{~N}$ abundance in naturally occurring substances and global assessment of denitrification from isotopic viewpoint. Geochem J 9: 139-148.

12. Mackenzie FT, Pigott JD (1981) Tectonic controls of Phanerozoic sedimentary rock cycling. J Geol Soc London: 138: 183-196.

13. Ivlev AA (2012) Oscillatory nature of metabolism and carbon isotope distribution in photosynthesizing cells Oscillatory nature of metabolism and carbon isotope distribution in photosynthesizing cells. In: Najafpour MM (Ed) Photosynthesis - fundamental aspects. Intech Publishers, Croatia 341- 366.

14. Derry LA, Kaufman AJ, Jacobsen SB (1992) Sedimentary cycling and environmental change in the Late Proterozoic: Evidence from stable and radiogenic isotopes. Geochim et Cosmochim Acta 56: 1317-1329.

15. Schobben M, Stebbins A, Ghaderi A, Strauss H, Korn H, et al. (2015) Flourishing ocean drives the end-Permian marine mass extinction. Proc Natl Acad Sci 112: 10298- 10303.

16. Bazhenova OK, Sokolov BA (2002) Origin of oil is the fundamental problem of natural science. Geologiya Nefti i Gaza N 1: 2-8.

17. Woods MA, Wilby PhR, Leng MJ, Rushton AWA, Williams M (2011) The Furongian (late Cambrian) Steptooean positive carbon isotope excursion (SPICE ) in Avalonia. J Geol Soc 168: 851-861.

18. Jenkyns HC, Grocke DR, Hesselbo1 SP (2001) Nitrogen isotope evidence for water mass denitrification during the early Toarcian (Jurassic) oceanic anoxic event. Paleoceanography 16: 593-603.

19. Riding JR, Leng MJ, Kender S, Hesselbo SP, Feist-Burkhardt S (2013) Isotopic and palynological evidence for a new Early Jurassic environmental perturbation. Paleogeography, Paleoclimatology, Paleoecology 374: 16-27.

20. Owens JD, Gill BC, Jenkyns HC, Batesa SM, Severmannd S, Kuypers MMM, et al. (2014) Sulfur isotopes track the global extent and dynamics of euxinia during Cretaceous Oceanic Anoxic Event 2. Proc Natl Am Sci U S A 110: 18407-18412.

21. Cors J, Heimhofer U, Adatte T, Hochuli PA, Huck S. et al. (2015) Climatic evolution across oceanic anoxic event 1 a derived from terrestrial palynology and clay minerals (Maestrat Basin, Spain)/ Geo Mag 152: P. 632-647.

22. Sabatino N, Neri R, Bellanca A, Jenkyns HC, Baudin F ,et al. (2009) Carbon-isotope records of the Early Jurassic (Toarcian) oceanic anoxic event from the Valdorbia (Umbria-Marche Apennines) and Monte Mangart (Julian Alps) sections: palaeoceanographic and stratigraphic implications. Sedimentology 56: 1307-1328.

23. Hesselbo SP, Jenkyns HC, Duarte LV, Oliveira LCV (2007) Carbon-isotope record of the Early Jurassic (Toarcian) oceanic anoxic event from fossil wood and marine carbonate (Lusitanian Basin, Portugal). Earth Planet Sci Lett 253: 455-470.

24. Korte Ch, Hesselbo SP (2011) Shallow marine carbon and oxygen isotope and elemental records indicate icehouse/greenhouse cycles during Early Urassic. Paleoceanography 26: 2011PA002160.

25. Algeo T, Rowe H, Hower JC, Schwark L, Herrmann A, et al. (2008) Changes in ocean denitrification during Late Carboniferous glacialinterglacial cycles. Nature Geoscience 1: 709 - 714.

26. Kotthoff U, Greenwood DR, McCarthy FMG, Müller-Navarra K, Prader S et al (2014) Late Eocene to middle Miocene (33 to 13 million years ago) vegetation and climate development on the North American Atlantic Coastal Plain (IODP Expedition 313, Site M0027). Clim Past 10: 1523-1539. 